\title{
STRASHILA INCREDIBILIS, A NEW ENIGMATIC MECOPTEROID INSECT WITH POSSIBLE SIPHONAPTERAN AFFINITIES FROM THE UPPER JURASSIC OF SIBERIA
}

\author{
BY A. P. RASNITSYN \\ Paleontological Institute, Russian Academy of Sciences \\ Profsoyuznaya 123, Moscow 117647 Russia
}

The Lower to Middle Jurassic and Lower Cretaceous deposits of Transbaikalia in East Siberia are rich in fossil insects (Zherikhin, 1978, 1985). The Late Jurassic insect assemblages are less diverse there. In part this is because only two fossil sites are better explored there, particularly those from the Uda and Bada (formerly Zun-Nemetey) Formations at the upper Uda River and near the town of Mogzon, respectively. More important, however, is that in both cases the source deposits are of essentially similar age and origin; all have an impoverished terrestrial insect fauna, for unknown reasons. And yet from there a very strange insect has been discovered which is described below.

Typified names of the higher taxa are used in the contribution, following to the proposal by Rohdendorf (1977, Rasnitsyn, 1982).

Superorder Papilionidea Laicharting 1781 (= Mecopteroidea auct.)

Order incertae sedis

Family Strashilidae, new family

Diagnosis (adult male). Differing probably from all adult insects in having abdomen with segmentary, strictly lateral, fleshy, long tubular appendages of obscure homology and function. Also by chelate hind leg, formed by crassate femur, basitarsus, and tibial apical process, with tarsus otherwise normal. Head hypognathous, with short moniliform antenna and possibly with short suctorial beak. Thorax completely wingless, lacking discrimen (midventral suture); terga narrow, band-like and seemingly subequal in length (pterothorax reduced); sterna exposed; coxae widely separating; tarsi long, 5-segmented. Male genitalia of primitive holometabolan type: probably retractile (with abdominal segment 9

Manuscript received 22 July 1992 
not fused in narrow, entire sclerotized ring), forming compact capsule with well developed aedeagus, volsellae and gonostyli, the latter two clearly articulated; lacking basal ring. Gonocoxae unknown to be either fused with each other or separated.

\section{Genus Strashila, new genus}

Adult male. Antenna 10-segmented, subequal to head width, with 3 basal segments each longer than any of succeeding ones. Head capsule subtriangular (at least when seen from below), possibly with inflated clypeus. Proboscis, if correctly interpreted, shorter than head (only reaching level of 1 st abdominal tergum), with apical ovoid structure. Thoracic terga short, seemingly simple, band-like (possibly except pronotum, which could form semiovoid shield covering much of head unless the line seen in the fossil is an occipital carina or something of this sort). Coxae short, sublateral. Fore and mid femur short, moderately stout; hind femur thick, crassate, with short, narrow stalk and longitudinal impression at flexor surface coadapted to tibia. Fore and mid tibiae subclavate; hind ones inflated similar to the femora except having still shorter stalk, elongated apically at flexor side into slightly curved process with narrowly rounded apex. Tarsi subequal in length, thin; with basitarsus slightly or, in hind leg, conspicuously thicker than distal segments, with long apical segment and moderately long, gently curved claws. Fore and mid basitarsus shorter than apical segment, hind basitarsus longer than apical segment and than tibial process. Abdomen lacking evident sclerotization except genitalia and rudimentary sclerotized strips on segment 8; segment 1 very short; next 5 ones normal, subequal, segment 7 shorter and more narrow; segment 8 still narrower; sternite 9 small. Lateral outgrowths long at segments 1-6; possibly shorter at segment 7; probably present but short at segment 8 , with ovoid apical structure of obscure nature seen in 1st pair. Male genitalia subovoid, hardly wider than long, with aedeagus moderately short and very wide, gonostylus and volsella subequal in size.

Female and immatures unknown.

Type species. S. incredibilis, new species.

Etymology. The generic name is a Russian word meaning scarecrow, and in general a nasty looking creature. Gender feminine. 
Strashila incredibilis, new species

Figures 1-4

Adult male. Size moderately small. Legs hairy, otherwise no conspicuous pubescence. Antenna almost as long as head is wide, weakly narrowed apically, with scape a minimum of 1.5 times as long as wide, with pedicel and 1st funicular segment slightly longer than wide, and with following segments changing from slightly to strikingly transverse. Ratio of femur, tibia, tarsal segments, and claw in fore leg ca. 1:2.5:0.7:0.6:0.6:0.6:0.8:0.5, in mid leg ca. 1:1.7:0.6:0.5:0.4:0.4:0.7:0.4, in hind one 1:1.1:0.35:0.15: $0.07: 0.07: 0.17: 0.12$. Hind femur and tibia 0.75 times as wide as mid femur is long. Gonocoxae combined 1.5 times as wide as long; gonostylus and volsella of subequal lengths, about half the length of the combined width of gonocoxae, both narrowed basally; volsella with asymmetrically placed process apically. Aedeagal valves wide, apically rounded and asymmetrical, contiguous mesally except at apex.

Body length, as preserved, $7.0 \mathrm{~mm}$, antenna $1.0 \mathrm{~mm}$, head length $1.0 \mathrm{~mm}$, width $1.25 \mathrm{~mm}$, fore femur length $0.7 \mathrm{~mm}$, tibia 1.6 $\mathrm{mm}$, tarsus with claw $2.5 \mathrm{~mm}$, mid ones, respectively, 1.0, 1.6, and $2.8 \mathrm{~mm}$, hind ones, respectively, $3.2,3.4$, and $3.0 \mathrm{~mm}$. Genital capsule width $1.0 \mathrm{~mm}$.

Type material. Holotype male, part and counterpart impression in tuffaceous argillite of lacustrine origin, PIN no. 3084/60, Russia, Chita Reg., Khilok District near Mogzon, Vishnevyi Site, profile 82, intervale $95 \mathrm{~m}$; Upper Jurassic, Bada Formation; L. P. Starukhina leg., 1990; kept in the Paleontological Institute, Russian Academy of Sciences, Moscow.

Etymology. The species name means incredible.

Discussion. The fossil is enigmatic because of its bizarre morphology. The capsule-like but otherwise primitive male genitalia (with articulated gonostylus and volsella, with a large aedeagus, and without a basal ring) rule out most insect taxa except the holometabolans and their possible ancestral group, the superorder Caloneuridea (Rasnitsyn, 1980, Rohdendorf and Rasnitsyn, 1980). Because of long time gap separating the last known, Late Permian Caloneurideans from Strashila, and because of lack of any specific similarity between them, it seems premature to hypothesize their direct relationship. That is why I shall consider only the holometabolan ancestry of Strashila. 


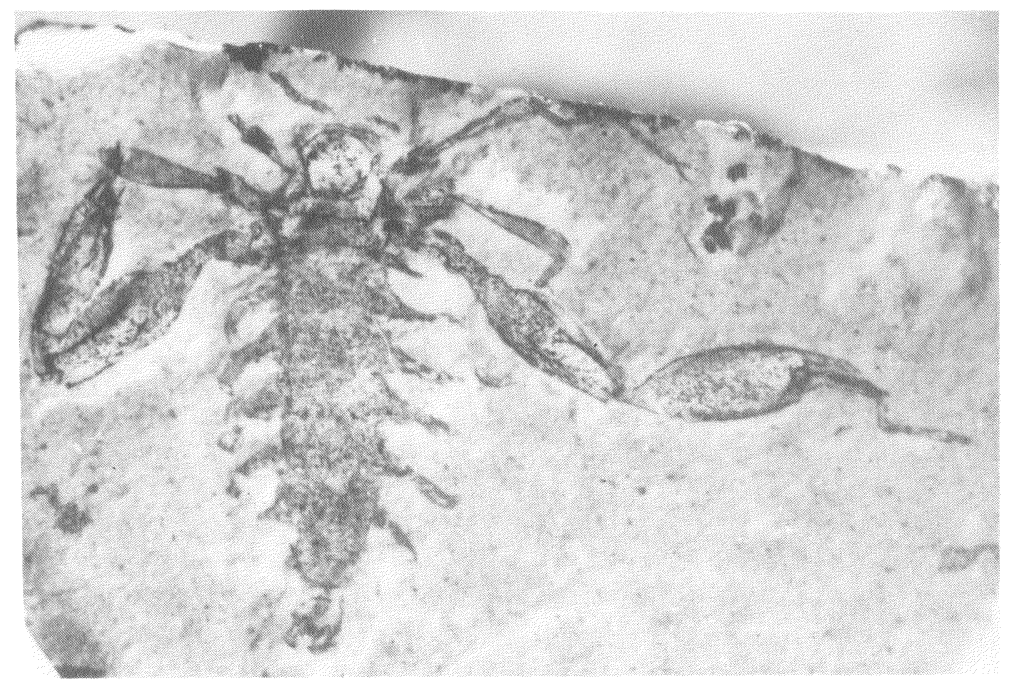

Fig. 1. Strashila incredibilis. Photograph of counterpart of the holotype male. Scale bar, $1 \mathrm{~mm}$.

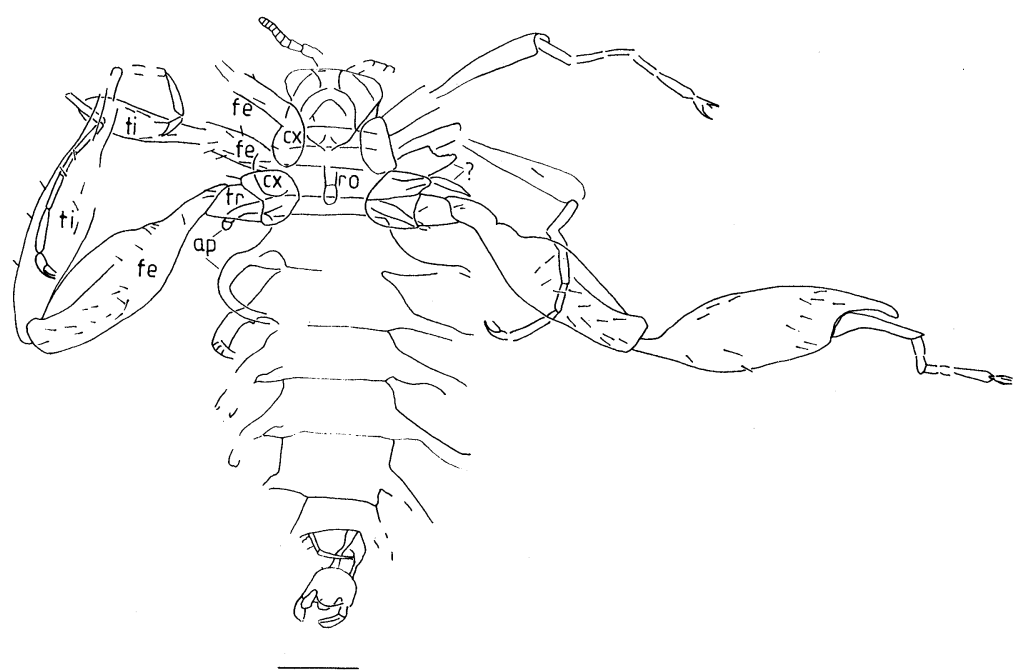

Fig. 2. S. incredibilis. Drawing of the holotype male seen from below (with contours of structures supposed lying more dorsal being interrupted when overlaid from below with structures of more ventral position). Scale bar, $1 \mathrm{~mm}$. Abbreviations: ap - lateral abdominal appendage, cx - coxa, fe - femur, ti - tibia, tr trochanter, ? - structure of obscure nature. 


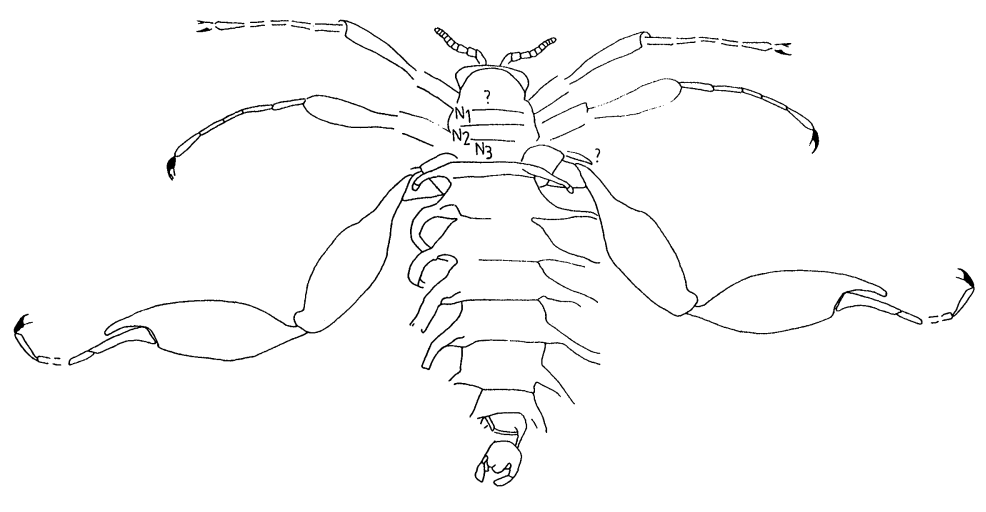

Fig. 3. Same as Fig. 2, except the insect is partly restored using better preserved member of each pair and shown as if seen from above with appendages displaced in more symmetrical position. Abbreviations: $\mathrm{N}_{1}, \mathrm{~N}_{2}, \mathrm{~N}_{3}-$ pro-, meso-, and metanotum.

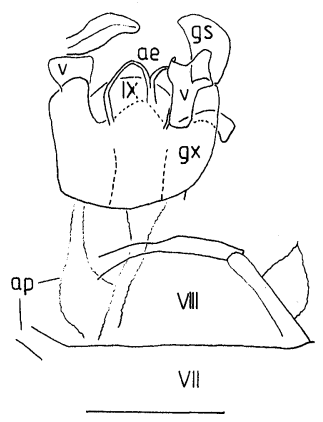

Fig. 4. S. incredibilis. Genitalia of the holotype male shown as if seen from above. Scale bar, $0.5 \mathrm{~mm}$. Abbreviations: ae - aedeagus, ap - lateral abdominal appendage, gs - gonostylus, $\mathrm{gx}$ - gonocoxa, $\mathrm{v}$ - volsella; figures refer to respective abdominal segments.

Within the holometabolous insects neither taxon possesses sound synapomorphies with our creature. One suggestive clue is the supposed presence of beak, presumably used for sucking but unfortunately with few details known. A proboscis is present in various blood sucking and insect predator dipterans, which is 
obvious convergence since these flies lack articulated volsellae and have (as do all dipterans) a metanotum that is highly reduced. Instead, fleas may be monophyletic with Strashila, though basing this merely on the presence of a beak. The hypothesis can be somewhat backed, however, by taking into account Saurophthyrus longipes Ponomarenko, 1976, (Figs. 5, 6) and Tarwinia australis Jell and Duncan, 1986 (Fig. 7), enigmatic fossils from the Early Cretaceous of East Siberia and Australia, respectively. They have already implicated in flea relationships (Riek, 1970, Ponomarenko, 1976, 1988, Hennig, 1981, Jell and Duncan, 1986). As for Saurophthyrodes mongolicus Ponomarenko, 1986, from the Late Cretaceous of Mongolia (Rasnitsyn, 1986), its relationship to Saurophthyrus is doubtful.

In spite of their striking differences, the above three fossils have in common short moniliform antennae and strongly elongate tarsi. Additionally, Strashila and Saurophthyrus have hypognathous heads with a beak (unknown yet for Tarwinia); widely separated coxae; long, gently curved claws; and weakly sclerotized, distensible abdomens. Saurophthyrus and Tarwinia share very long, thin legs with relatively short tibiae, while Saurophthyrus has bands of short spines described as ctenidia (unknown in Tarwinia, absent in Strashila).

Important is the bionomical interpretation of Saurophthyrus morphology. Ponomarenko $(1976,1988)$ has found it comparable to blood sucking parasites of bats which frequent their wing membrane. Saurophthyrus possibly parasitized pterosaurs. Strashila conceivably also frequented pterosauran wings, with long legs permitting to hold fast on the host wing membrane despite its permanent deformation, and with the tibio-basitarsal pincers used possibly to fix on the host hairs. At least some pterosaurs were indeed hairy and, by inference, warm-blooded (Sharov, 1971). Unlike Strashila and Saurophthyrus, Tarwinia had the body more compressed and better suited to dwell in dense body fur. Its long legs, however, indicate ability to frequent the wing membrane as well.

All three fossils along with the fleas could be tentatively hypothesized as parasites of warm-blooded animals. The three fossils can be further supposed to be synapomorphic in the parasitism of pterosaurs, while Strashila and Saurophthyrus reveal an 


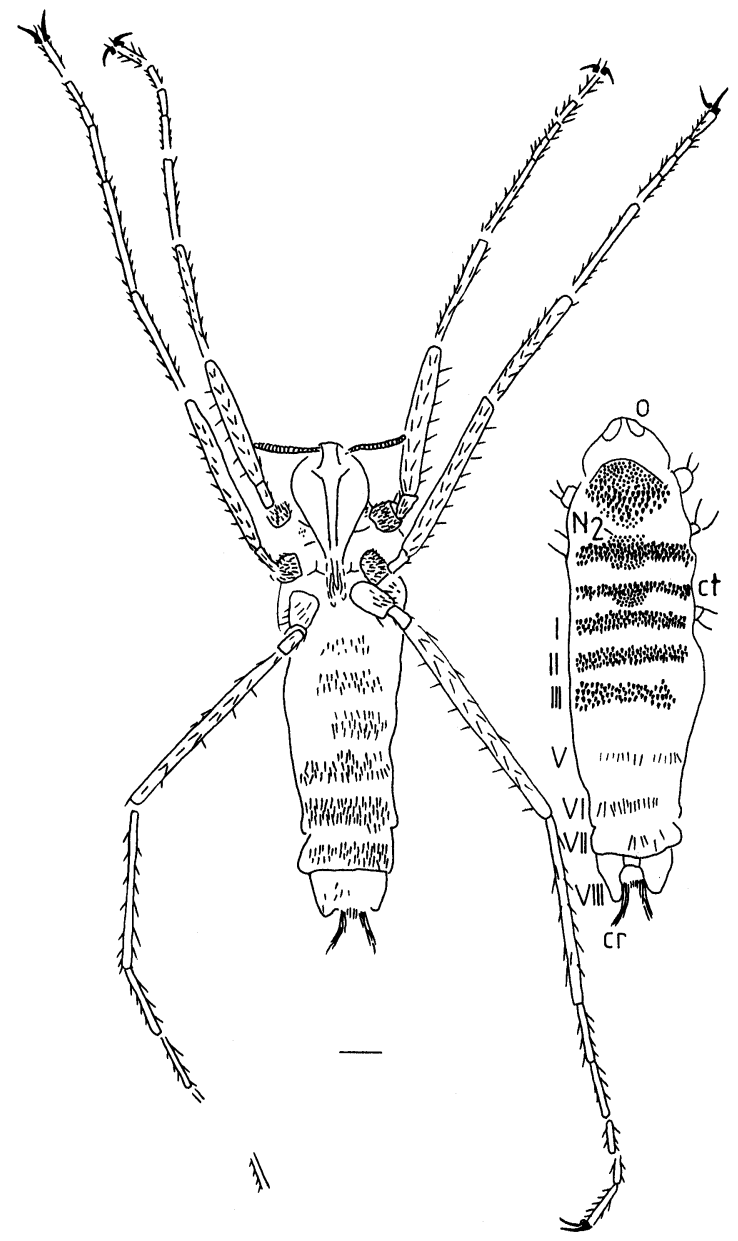

Fig. 5. Saurophthyrus longipes Ponomarenko, 1976. Holotype female (combined from various figures in Ponomarenko, 1976, with legs displaced in more symmetrical position). Ventral and, for the body alone, dorsal view. Scale bar, $1 \mathrm{~mm}$. Abbreviations: cr - cercal brush, ct - ctenidium, o - eye, others as on previous figures. 


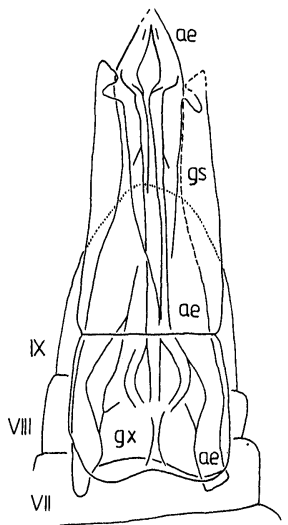

Fig. 6. S. longipes. Genitalia of the male specimen PIN \#3064/2379 shown as if seen from above. Scale bar, $1 \mathrm{~mm}$. Abbreviations as on Fig. 4.

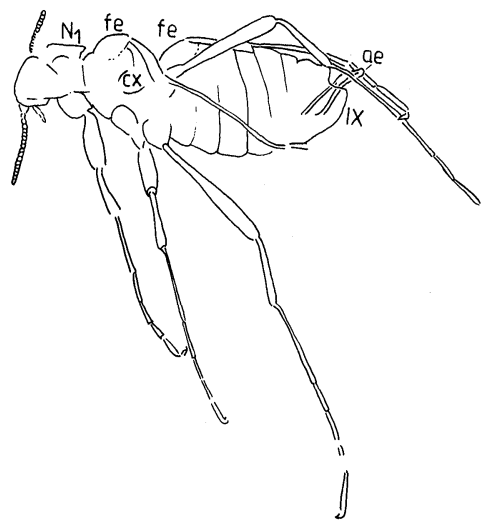

Fig. 7. Tarwinia australis Jell and Duncan, 1986. Drawing of the holotype male seen from below (traced from photograph). Scale bar, $1 \mathrm{~mm}$. Abbreviations as on previous figures. 
additional putative synapomorphy in adaptations to frequent the wing membrane. Or reverse, parasitizing the pterosauran wings can be hypothesized as the synapomorphy of the entire clade comprising the fleas and the fossils. Then the fleas, Saurophthyrus, and by inference also Tarwinia become synapomorphic in acquiring ctenidia, while Tarwinia and the fleas show synapomorphy in characters related to life in the body fur (subcontiguous coxae, compressed body, more sclerotized abdomen). The last version seems parsimonious, for otherwise ctenidia either originated twice (in the fleas and in Saurophthyrus), or were lost secondarily in Strashila. The preferred explanation better fits the geological succession of the fossils as well, Strashila being the oldest and Tarwinia the youngest.

Testing the above hypotheses using independent evidence is important, and morphology of the male genitalia could be most useful. It is known in some detail for Strashila and Saurophthyrus and very little for Tarwinia (Figs. 4, 7, 8). Unfortunately there has been only limited success, for the most striking character state, the articulated volsellae, is visible only in Strashila. The fossils differ symplesiomorphically from the fleas as well as from scorpionflies in retaining a well developed aedeagus and articulated volsellae. Tarwinia and Saurophthyrus show a synapomorphy in the very elongated aedeagus, while the long internal aedeagal structures in fleas could be its further modification.

Unfortunately the pterosaurian hypothesis lacks paleoecological support. The deposits which yielded Strashila have failed to reveal any terrestrial vertebrates. Those which have produced Tarwinia and Saurophthyrus have produced neither reptiles nor mammals but only bird feathers (Kurochkin, 1985, Drinnan and Chambers, 1986).

It seems reasonable to suppose that the fossils in question form with the fleas a sister group of at least mecopterans and dipterans (perhaps of all other mecopteroids, as free volsellae would indicate). However, the hypothesis is based largely on features apparently associated with parasitic habits and, thus, possibly convergent. Until additional evidence is gathered in favor of monophyly of the clade, it seems premature to create a taxon, e.g., a suborder within the order Pulicida (= Siphonaptera), in which to place the fossils. 
The lateral abdominal outgrowths of Strashila may indicate its aquatic habits. This does not seem likely, however. No other aquatic adaptation is found in Strashila, and the outgrowths are otherwise unknown adult insects, either aquatic or terrestrial.

\section{SUMMARY}

Strashila incredibilis and the family Strashilidae are described from the Late Jurassic of Transbaikalia. This enigmatic, apterous family in the mecopteroids is possibly a pterosaur parasite similar to the Early Cretaceous Saurophthyrus and Tarwinia. All available evidence indicates all three form a monophyletic group with the fleas. Genitalic characters indicate that Strashila and, by inference, all the above clade represent a sister group of mecopterans and dipterans combined unless of an even more inclusive group.

\section{ACKNOWLEDGEMENTS}

The present contribution has become possible thanks to Dr. D. G. Furth, The Managing Editor, who has invited me to contribute to the Frank M. Carpenter Psyche Festschrift, Dr. L. P. Starukhina (Chitageologiya Co., Chita) who has collected the holotype and made it available for study, and Dr. A. G. Ponomarenko (Paleontological Institute, Russian Academy of Science, Moscow) who has supplied me with unpublished information concerning Saurophthyrus and Tarwinia, including the photograph of the Tarwinia holotype sent to him by Dr. E. F. Riek.

\section{REFERENCES}

Drinnan, A. N. AND T. C. Chambers

1986. Flora of the Lower Cretaceous Koonwarra Fossil Bed (Korumburra Group), South Gippsland, Victoria. Mem. Ass. Australas. Palaeontols 3: $1-77$.

HENNIG, W.

1981. Insect phylogeny. Chichester etc., J. Wiley \& Sons. 514 pp.

JELL, P. A. AND P. M. DunCAN

1986. Invertebrates, mainly insects, from the freshwater, Lower Cretaceous, Koonwarra Fossil Bed (Korumburra Group), South Gippsland, Victoria. Mem. Ass. Australas. Palaeontols 3: 111-205.

KurochKIn, E. N.

1985. Lower Cretaceous birds from Mongolia and their evolutionary significance. Acta XVIII Congr. Internat. Ornitol., Moscow 1982. Vol. 2. Moscow, Nauka Press: 191-199. 
Ponomarenko, A. G.

1976. The new insect from the Cretaceous of Transbaicalia a probable parasite of pterosaurien. Paleontol. Zhurn. no 3: 102-106 (in Russian).

1988. The origin of Fleas: the evidences from fossil record. Symposium: The results and perspectives of further research of Siphonaptera in Palearct from the aspect of their significance for practice [sic!]. Bratislava 6.6.-11.6.1988. Bratislava: 3-7.

RASNitsyn, A. P.

1980. Origin and evolution of Hymenoptera. Trans. Paleontol. Inst. Acad. Sci. USSR. 174. Nauka Press, Moscow. 192 pp. (in Russian).

1982. Proposal to regulate the names of taxa above the family group. Z. N. (S.) 2381. Bull. Zool. Nom. 39: 200-207.

RASnitsyn, A. P. (ed.)

1986. Insects in the Early Cretaceous ecosystems of the West Mongolia. Trans. Joint Soviet-Mongol. Paleontol. Exped. 28. Nauka Press, Moscow. 215 pp. (in Russian).

RIEK, E. F.

1970. Lower Cretaceous fleas. Nature (London) 227: 746-747.

ROHDENDORF, B. B.

1977. The rationalization of names of higher taxa in zoology. Paleontol. Zhurn. no. 3: 11-21 (in Russian, translated into English in Paleontol. J. 1977, 11: 149-155).

Rohdendorf, B. B. AND A. P. RASNitsyn (eds.)

1980. Historical development of the class Insecta. Trans. Paleontol. Inst. Acad. Sci. USSR. 175. Nauka Press, Moscow. 269 pp. (in Russian).

Sharov, A. G.

1971. New flying reptiles from the Mesozoic of Kazakhstan and Kirghizia. Trans. Paleontol. Inst. Acad. Sci. USSR. 130. Nauka Press, Moscow: 104-113 (in Russian).

ZHERIKHIN, V. V.

1978. Development and changes of the Cretaceous and Cenozoic faunal assemblages (Tracheata and Chelicerata). Trans. Paleontol. Inst. Acad. Sci. USSR 165. Nauka Press, Moscow. 198 p. (in Russian).

1985. Insects. In: Rasnitsyn A. P. (ed.) 1985. Jurassic non-marine biocenoses of South Siberia and neighbor territories. Trans. Paleontol. Inst. Acad. Sci. USSR. 213. Nauka Press, Moscow: 100-131 (in Russian). 

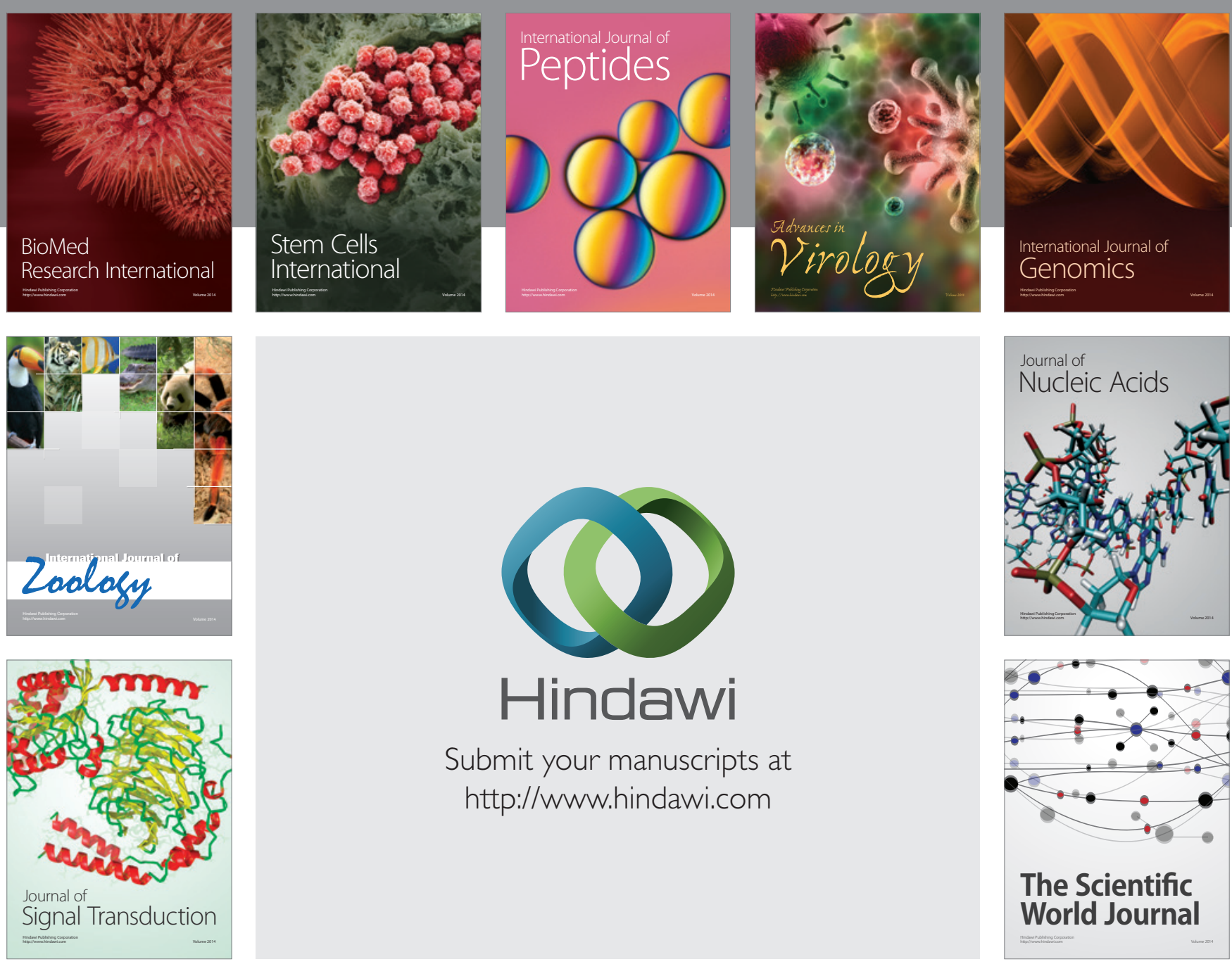

Submit your manuscripts at

http://www.hindawi.com
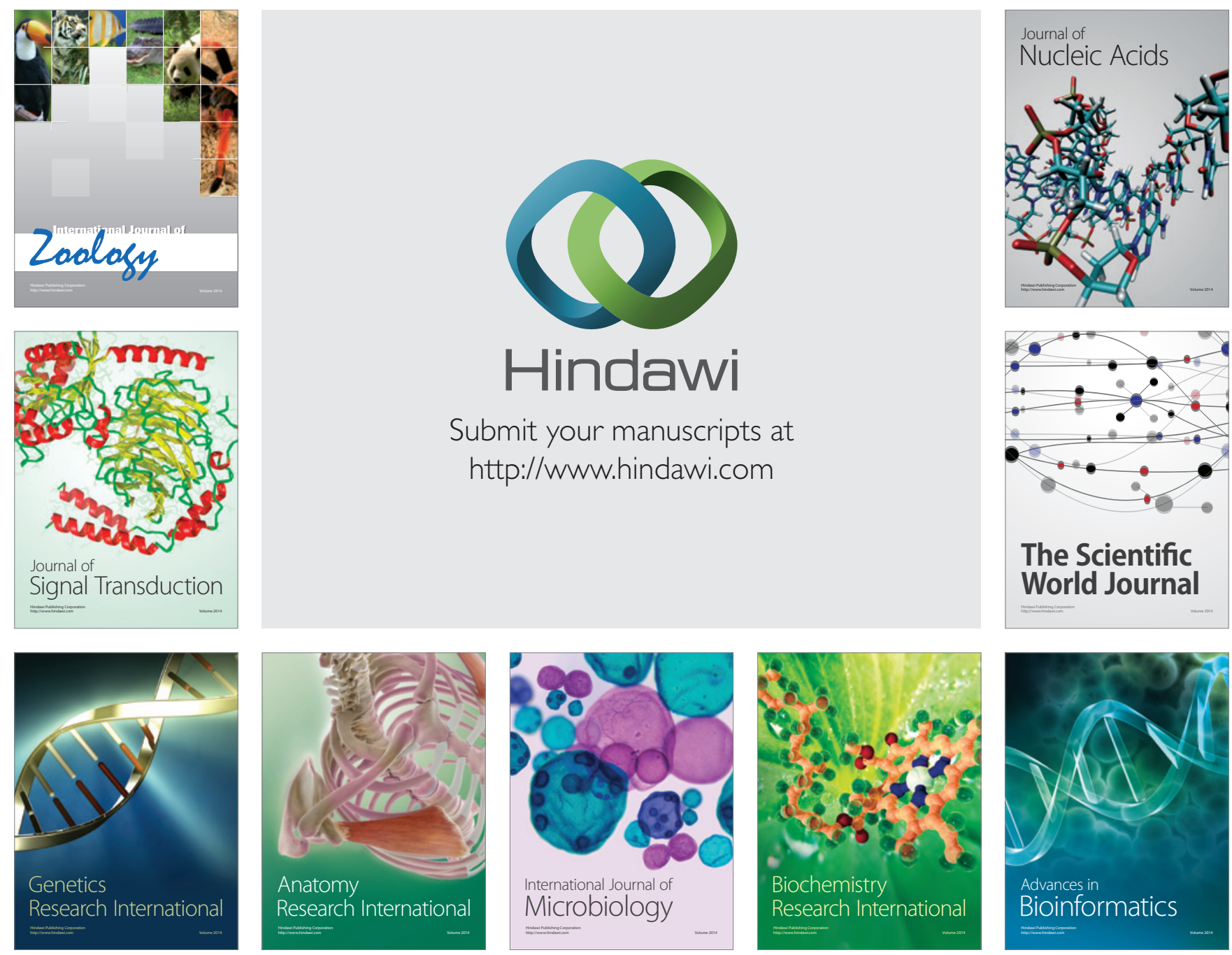

The Scientific World Journal
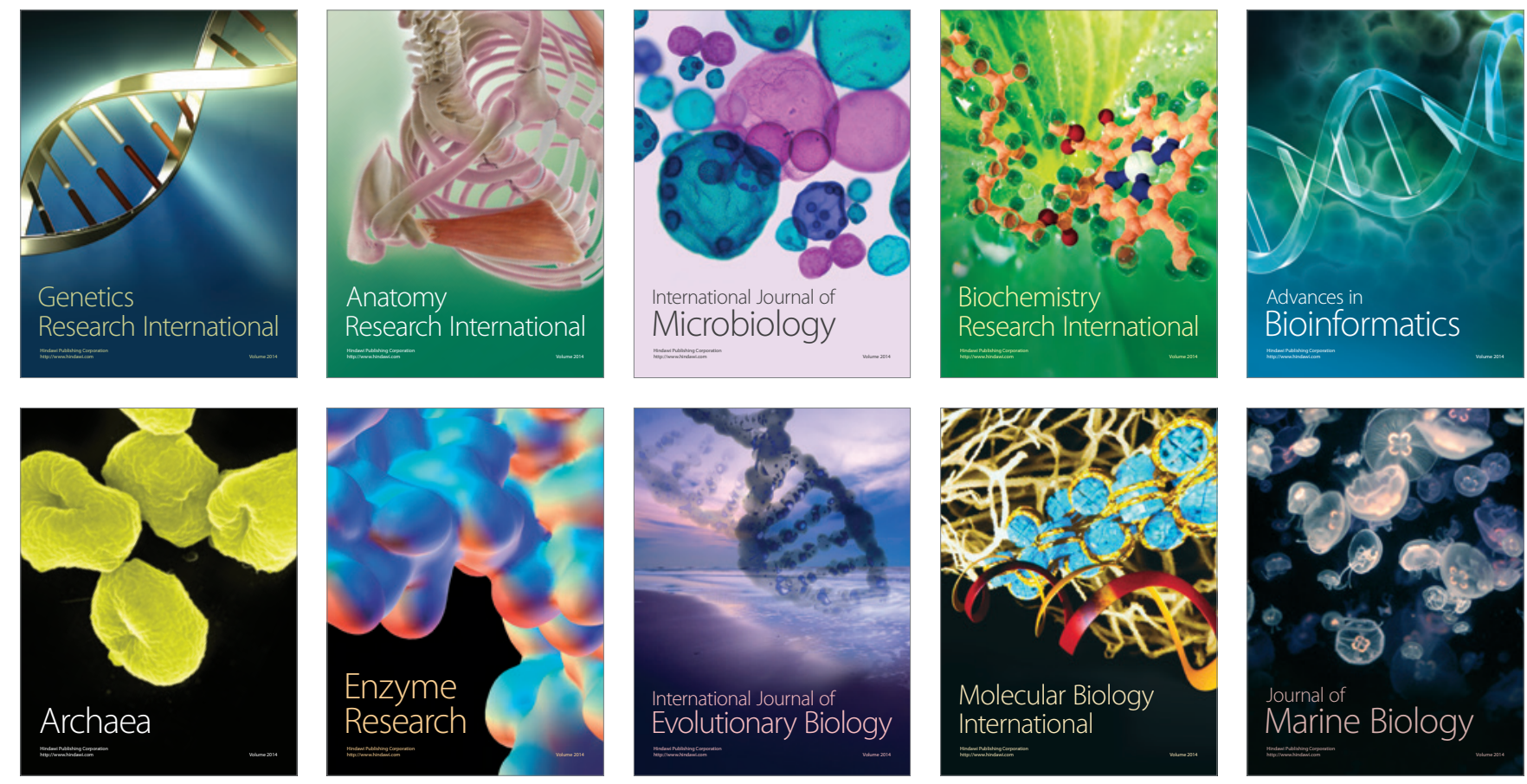